JURNAL PANGKAJA PROGRAM PASCASARJANA UNIVERSITAS HINDU NEGERI I GUSTI BAGUS SUGRIWA DENPASAR
Vol.24, No. 2, September 2021

ISSN : 1412-7474 (Cetak)

ISSN : 2623-2510 (Online)

http://ejournal.ihdn.ac.id

\title{
FUNGSI DAN PERANAN PEREMPUAN HINDU DALAM PELAKSANAAN YADNYA DI BALI
}

\author{
Ni Gusti Ayu Kartika \\ Universitas Hindu Negeri I Gusti Bagus Sugriwa Denpasar \\ Email: kartikanigustiayu@gmail.com
}

\begin{abstract}
ABSTRAK
Bali merupakan salah satu daerah yang sangat menjunjung tinggi budaya, dimana sampai saat ini budaya bali masih berakar kuat di setiap gerak langkah kehidupan masyarakatnya. perempuan bali memiliki nilai tambah yang berperan penting dalam melestarikan budaya, karena perempuan bali menduduki posisi yang sangat strategis sebagai sosok panutan dalam pelaksanaan budaya. perempuan bali memiliki triple roles yakni peran keluarga, peran ekonomi dan peran adat keagamaan. pelaksanaan peran yang maksimal, baik di lingkungan keluarga, lingkungan tempat bekerja, maupun masyarakat umum (komunitas sosial budaya/adat keagamaan). Tujuan dari penelitian ini adalah untuk memaparkan fungsi dan peranan perempuan hindu dalam pelaksanaan yadnya di bali mengingat posisi wanita memiliki peran dan kedudukan yang sangat penting dalam ajaran agama hindu, bahkan wanita merupakan tiang yadnya yang memiliki peran mulai dari persiapan dan pelaksanaan yadnya. karena masyarakat hindu di bali yang begitu kental dengan pelaksanaan upacara keagamaan, sehingga kaum wanitanya hendaklah juga terampil dalam membuat sarana upacara dan ulet dalam hal melakukan aktifitas yadnya. penelitian ini menggunakan metode kualitatif. Penelitian ini berusaha mengungkap fungsi dan peranan perempuan Hindu dalam pelaksanaan yadnya di Bali hasil penelitian menunjukan bahwa bentuk-bentuk peranan perempuan di Bali khususnya dalam kegiatan ritual keagamaan kebanyakan berperan dalam mengatur acara ritual secara keseluruhan. Maksudnya adalah para perempuan Bali dari awal dan dari jauh-jauh hari sudah mempersiapkan upacara kegiatan ritual yang akan dilaksanakan hampir setiap bulannya bahwa di Bali banyak sekali kegiatan yang benuansa ritual keagamaan
\end{abstract}

Kata Kunci : Fungsi, Perempuan, Yadnya

\section{ABSTRACT}

Bali is one of the areas that highly upholds culture, where until now Balinese culture is still firmly rooted in every step of the life of its people. Balinese women have added value that plays an important role in preserving culture, because Balinese women occupy a very strategic position as role models in the implementation of culture. Balinese women have triple roles, namely the role of the family, the role of the economy and the role of religious customs. implementation of the maximum role, both in the family environment, workplace environment, and the general public (social cultural/religious community). The purpose of this study is to describe the function and role of Hindu women in the implementation of yadnya in Bali considering the position of women has a very important role and position in the teachings of Hinduism, even women are the pillars of yadnya who have a role starting from the preparation and implementation of yadnya. because the Hindu community in Bali 
is so thick with the implementation of religious ceremonies, so that the women should also be skilled in making ceremonial facilities and be tenacious in carrying out yadnya activities. This study uses a qualitative method. This study seeks to reveal the functions and roles of Hindu women in the implementation of yadnya in Bali. The results show that the forms of women's roles in Bali, especially in religious ritual activities, mostly play a role in regulating the overall ritual event. The point is that Balinese women from the beginning and from a long time have prepared ritual activities that will be carried out almost every month that in Bali there are many activities that are religious rituals.

\section{Keywords: Function, Women, Yadnya}

\section{PENDAHULUAN}

Fenomena kehidupan sosial perempuan memang sangat menarik jika dikaji dari sudut pandang filosofis dan ideologis. Dimana dalam tulisan ini menyasar fungsi dan peranan perempuan Bali terhadap konteks ritual upacara keagamaan. Agama Hindu khususnya yang ada di Bali seakan tidak pernah berhenti dalam segala bentuk aktivitas dan kegiatannya. Hampir setiap hari bahkan setiap saat umat Hindu di Bali melakukan persembahan berupa yadnya sesa baik itu dalam skala kecil, maupun skala besar. Semua kegiatan tersebut selalu mengikat dan membelenggu perempuan-perempuan khususnya yang ada di desa tempat tinggal perempuan Bali.

Memang pada umumnya didalam konteks suatu Ritual agama Hindu peranan perempuan lebih dominan dari laki-laki, karena laki-laki dianggap sebagai kepala keluarga dimana laki-laki adalah bertanggung jawab menafkahi keluarga sehingga sedikit sekali waktu untuk memikirkan atau bahkan mengambil suatu pekerjaan yang ada kaitannya dengan Ritual keagamaan, Perempuan Bali beranggapan bahwa semua tugas yang ada hubunganya dengan ritual sudah sepantasnya diambil oleh kaum perempuan.

Wanita dalam theologi Hindu bukanlah merupakan serbitan kecil dari personifikasi lelaki, tetapi merupakan suatu bagian yang sama besar, sama kuat, sama menentukan dalam perwujudan kehidupan yang utuh. Istilah theologisnya ialah "Ardhanareswari". Ardha artinya setengah, belahan yang sama. Nara artinya (manusia) laki-laki. Iswari artinya (manusia) wanita. Tanpa unsur kewanitaan, suatu penjelmaan tidak akan terjadi secara utuh dan dalam agama Hindu unsur ini mendapatkan porsi yang sama sebagaiman belahan kanan dan kiri pada manusia. Sebagaimana belahan bumi atas yaitu langit dengan belahan bumi bawah yaitu bumi yang kedua-duanya mempunyai tugas, kekuatan yang seimbang guna tercapainya keharmonisan dalam alam dan kehidupan manusia di alam ini.

Dalam Siwatattwa dikenal konsep Ardhanareswari yaitu simbol Tuhan dalam manifestasi sebagai setengah purusa dan pradana. Kedudukan dan peranan purusa disimbolkan dengan Siwa sedangkan Pradana disimbolkan dengan Dewi Uma. Di dalam proses penciptaan, Siwa memerankan fungsi maskulin sedangkan Dewi Uma memerankan fungsi feminim. Tiada suatu apa pun akan tercipta jika kekuatan purusa dan pradana tidak menyatu. Penyatuan kedua unsur itu diyakini tetap memberikan bayu bagi terciptanya berbagai mahluk dan tumbuhan yang ada.

Makna simbolis dari konsep Ardhanareswari, kedudukan dan peranan perempuan setara dan saling melengkapi dengan laki-laki bahkan sangat dimuliakan. Tidak ada alasan serta dan argumentasi teologis yang menyatakan bahwa kedudukan perempuan berada di bawah lakilaki. Itulah sebabnya di dalam berbagai sloka Hindu dapat ditemukan aspek yang menguatkan kedudukan perempuan di antara laki-laki. 


\section{PEMBAHASAN}

\section{1 Peranan Perempuan Hindu Dalam Pelaksanaan Yadnya Di Bali}

Jika berbicara mengenai 'peranan', stereotife akan tertuju pada elemen-elemen dasar yang tersusun dengan tatanan yang sistematis. Kedudukan 'peranan' sama dengan bentuk, sehingga kadang-kadang orang sulit membedakan penggunaan kata bentuk dengan kata peranan. Dalam kehidupan sosial kemasyarakatan, perempuan Hindu sangat kental dengan pola hidup beryadnya. Beryadnya bukan saja berarti mempersembahkan segala sesuatunya kehadapan Tuhan atau Ida Sang Hyang Widhi Wasa dengan penuh keikhlasan, tetapi melainkan memiliki peranan yang lebih penting dalam harmonisasi komunikasi yang terjalin dalam sebuah rangkaian konteks pelaksanaan ritual umat Hindu.

Sedangkan perempuan adalah sebutan yang digunakan untuk manusia yang berjenis kelamin atau bergender perempuan. Lawan jenis dari wanita adalah pria atau laki-laki. Perempuan adalah panggilan umum yang digunakan untuk menggambarkan wanita dewasa. Perempuan berasal dari Bahasa Sanskrit, yaitu Svanittha, di mana kata Sva artinya "sendiri" dan Nittha artinya "suci". Jadi Svanittha artinya "menyucikan sendiri" kemudian berkembang menjadi pengertian tentang manusia yang berperan luas dalam Dharma atau "pengamal Dharma". Menurut konsep Jawa Kuno bahwa Wanita berasal dari kata Wani (berani) dan Nata/Tata (teratur). Artinya bahwa seorang perempuan harus berani mengatur rumah tangga dan mendidik anak.

Dalam pandangan Agama Hindu, seorang perempuan mempunyai peranan yang penting yaitu sebagai "sarana" terwujudnya Punarbhava atau reinkarnasi. Dari penjelasan ini juga berkembang istilah Sukla Svanittha yang artinya "bibit" atau janin yang dikandung oleh manusia. Sejak seorang perempuan itu mengalami menstruasi pertama dalam hindupnya, seorang perempuan sudah dianggap dewasa, dan juga merupakan suatu ciri atau tanda bahwa ia subur hingga mempunyai kemampuan untuk hamil. Oleh karena itu peradaban lembah Sungai Indus di India sejak beribu tahun lampau senantiasa menghormati dan memperlakukan perempuan secara hati-hati terutama ketika ia saat sedang menstruasi.

Peranan wanita sangat penting dalam kehidupan seorang umat hindu baik dia sebagai ibu maupun anak putri, karena sistem adatlah yang memberikan porsi lain bukan Hindu jadi selayaknya generasi kita sekarang lebih baik menjaga dan memberikan bimbingan tentang Hindu kepada putri dan wanita hindu termasuk sebagai kaum lelaki yang tidak semestinya mengabaikan kewajiban perempuan Bali terhadap leluhur. Posisi Wanita memiliki peran dan kedudukan yang sangat penting dalam ajaran agama Hindu, bahkan wanita merupakan tiang yadnya yang memiliki peran mulai dari persiapan dan pelaksanaan yadnya. Karena masyarakat Hindu di Bali yang begitu kental dengan pelaksanaan upacara keagamaan, sehingga kaum wanitanya hendaklah juga terampil dalam membuat sarana upacara dan ulet dalam hal melakukan aktifitas mejejaitan / reringgitan tetandingan banten.

Urusan mejejahitan dalam kehidupan rumah tangga dikerjakan oleh kaum perempuan, proses belajar mejejahitan juga tersosialisai dalam lingkungan keluarga, maupun dalam komunitas banjar atau desa pekraman. Proses belajar mejejahitan sebenarnya terjadi secara alami, karena setiap anak perempuan yang terlahir dalam keluarga Hindu memang ada tuntutan seminimal mungkin harus bisa mejejahitan guna membuat canang yang diaturkan setiap ada rerainan, seperti kajeng kliwon, purnama, tilem, buda kliwon dan sebagainya. Peranan perempuan Hindu terutama ketika sudah menjadi seorang ibu sangat bertanggung jawab dan berperan untuk mendidik anak perempuan belajar mejejahitan. Disadari atau tidak di sini peranan kaum ibu sebagai awal terjadinya proses belajar untuk melatih anak perempuan mejejahitan. Belajar mejejahitan bagi anak perempuan sudah dilakukan sejak usia dini, diawali dulu dengan membantu ibunya mengambil pekerjaan yang ringan. Tradisi belajar seperti ini yang masih berlangsung sampai saat ini di dalam keluarga yang diwariskan secara turun-temurun. 
berikut :

Di dalam kitab suci Weda juga terdapat sloka tentang peranan Wanita yakni sebagai

\section{Patni sukrtam bibharti}

(Yajurveda XIX.94)

Artinya :

Istri hendaknya taat melaksanakan upacara-upacara keagamaan

Yantrīrād yantryasi yaman̄̄

Dhruvā'si dharitrī, işe tvorje tvā

Rayyai tvā poşāya tvā lokam tā indram

(Yajurveda XIV.22)

Artinya :

Wanita adalah pengawas keluarga, dia cemerlang, dia mengatur yang lain-lain dan dia sendiri yang taat kepada aturan-aturan, dia adalah aset keluarga sekaligus yang menopang (kesejahteraan) keluarga

Penjelasan :

Sloka ini menjelaskan betapa besarnya peranan wanita yang begitu mulia sebagai pengawas keluarga dan merupakan sinar bagi keluarga karena kecemerlangan yang ia miliki untuk membawa pada kebahagiaan. Disamping itu wanita merupakan sebagai pemimpin keluarga karena sebagai pengatur dan sebagai pelaku dari aturan tersebut dan sekaligus penopang keluarga dalam suka maupun duka.

Samrajni svasrvam bha va

Nanandari samrajni bhava

Samrajni adhi devrsu

Artinya :

(Rgveda X.85.46)

Wahai mempelai wanita, jadilah nyonya rumah dan bimbinglah ayah mertua, ibu mertua, saudara dan saudari ipar

Penjelasan: Dalam sloka ini menjelaskan bahwa wanita merupakan pembimbing dari sebuah keluarga ataupun sebagai pembimbing dari ayah, ibu mertua dan saudara, saudari ipar. Wanita sangat berperan penting untuk membangun keluarga yang harmonis dan sejahtera dalam mengarungi bahtera rumah tangga. Sehingga wanita mempunyai peranan sangat penting dalam sebuah keluarga.

Yatra Naryastu Pujyante,

Ramante Tatra Devatah,

Yatraitastu Na Pujyante,

Sarvastatraphalah Kriyah

(Manawa Dharmashastra.III.56)

artinya :

Di mana wanita dihormati, di sanalah pada Dewa-Dewa merasa senang, tetapi di mana perempuan Bali tidak dihormati, tidak ada upacara suci apapun yang akan berpahala. 
Socanti Jamayo Yatra,

Vinasyatyacu Tatkulam,

Na Socanti Tu Yatraita,

Vardhate Taddhi Sarvada

(Manawa Dharmashastra.III.57)

artinya :

Di mana wanita hidup dalam kesedihan, keluarga itu akan cepat hancur, tetapi di mana wanita tidak menderita, keluarga itu akan selalu bahagia.

Jamayo Yani Gehani,

Capantya Patri Pujitah,

Tani Krtyahataneva,

Vinasyanti Samantarah

(Manawa Dharmashastra.III.58)

artinya :

Rumah di mana wanitanya tidak dihormati sewajarnya, mengucapkan kata-kata kutukan, keluarga itu akan hancur seluruhnya seolah-olah dihancurkan oleh kekuatan gaib.

Bentuk-bentuk peranan perempuan di Bali khususnya dalam kegiatan ritual keagamaan kebanyakan berperan dalam mengatur acara ritual secara keseluruhan. Maksudnya adalah para perempuan Bali dari awal dan dari jauh-jauh hari sudah mempersiapkan upacara kegiatan ritual yang akan dilaksanakan hampir setiap bulannya bahwa di Bali banyak sekali kegiatan yang benuansa ritual keagamaan. rerahinan berdasarkan sasih, misalnya yakni hari suci Nyepi dan hari suci Siwalatri. Di samping itu pula, di Bali juga terdapat hari raya yang berdasarkan berdasarkan wuku, yaitu; Tumpek Wariga/Pengarah yang jatuhnya setiap enam bulan sekali pada wuku wariga, Tumpek Krulut, hari raya Galungan, Kuningan, Saraswati dan Pagerwesi serta masih banyak jenis hari raya berdasarkan $w u k u$.

Dari serangkaian kegiatan itu, bentuk peranan perempuan di Bali selalu berkaitan dan berkesinambungan. Misalnya sebulan sebelum galungan, pihak perempuan sudah mengadakan penjajagan mengenai bahan-bahan apa saja yang perlu dipersiapkan untuk keperluan upacara. Kemudian setelah waktu satu minggu menjelang galungan, para perempuan sudah sibuk menyiapkan segala sesuatunya. Pada acara piodalan berlangsung, peranan perempuan lebih kelihatan lagi, yaitu dari penyiapan sarana banten, menghaturkan sesajen dari semua yang dihantarkan pemangku. Demikian pula, upacara-upacara piodalan di tempat/pura yang lain, perananya sangat mendominasi. Jadi perempuan di Bali lebih memegang peranan dalam bidang pelaksanaan ritual keagamaan.

\subsection{Fungsi Perempuan Bali Dalam Pelaksanaan Yadnya Umat Hindu Di Bali.}

Perempuan dalam agama Hindu memiliki peranan yang penting yang tidak terpisahkan dengan peran laki - laki di dalam kehidupan masyarakat dari jaman ke jaman. Tidak mengherenkan jika dilihat dari konsep ajaran agama Hindu di dalam Siwa Tatwa yang tertulis bahwa kehidupan mahluk terutama manusia karena perpaduan antara unsur suklanita dan swanita. Tanpa swanita tidak mungkin ada dunia yang harmonis, demikian dicantumkan pentingnya kedudukan perempuan Hindu dalam kehidupan. Dalam kebudayaan Bali, keunikan dan kekhasan kebudayaan tidak pernah lepas dari kebudayaan patriarki dimana dinyatakan bersumber dari adanya konsep purusha dan pradhana yang terdapat dalam 
masyarakat, konsep seperti ini lebih dikenal dengan hal-hal yang berkaitan dengan laki-laki atau purusha, dan hal-hal yang berkaitan dengan perempuan atau pradhana (Wiasti, 2006).

Ada dua pendekatan yang bisa dipergunakan dalam menganalisis fungsi perempuan Bali, khususnya yang ada di Bali dalam peranannya pada pelaksanaan ritual umat hindu, yakni pendekatan struktural dan pendekatan fungsional. Struktur memandang perempuan sebagai klasifikasi sosial, sementara fungsi memandang perempuan sebagai peranan dalam pekerjaan. Kini, penulis mencoba mengkolaborasikan atau memadukan kedua pendekatan tersebut.

Pendekatan fungsi bertujuan mencari tahu apa fungsi perempuan Bali dalam pelaksanaan ritual umat Hindu khususnya di Bali bahwa keberadaan warga perempuan khususnya sudah sejak lama berfungsi sebagai pelaku-pelaku utama dalam konteks kegiatan upacara yadnya. Fungsi perempuan Bali tentunya secara alamiah perempuan Bali lakoni dalam memerankan tugas-tugas perempuan Bali dalam konteks upacara ritual. Maksudnya adalah perempuan Bali tanpa ada yang memerintahkan si A atau si B mengambil pekerjaan ini atau pekerjaan itu, perempuan Bali tanpa berpikir panjang langsung menggarap pekerjaan itu sesuai dengan kemampuan dan skill yang perempuan Bali miliki. perempuan-perempuan di Bali sebenarnya memiliki ciri khas, yaitu seperti disebutkan dalam istilah Bali "elek ken timpal" artinya "malu kepada teman". Dengan menganut asas seperti ini, jiwa semangat gotong royong masih tertancap dalam hati perempuan Bali. Sehingga khususnya dalam proses pelaksanaan upacara ritual keagamaan, perempuan Bali saling membantu tanpa menyoalkan bekerja dengan siapa pun. Jadi masih saat ini, fungsi perempuan di Bali dalam konteks ritual keagamaan masih bisa dipertahankan.

\section{Fungsi Sosial Masyarakat}

Budaya perempuan Bali umumnya dikatakan sebagai kebiasaan yang terbentuk secara alami dalam perilaku sehari-hari dan diwujudkan dalam bentuk simbol yang ekspresif, Budaya perempuan mempunyai berbagai macam fungsi; salah satu fungsi yang mendatar adalah "fungsi sosial". Fungsi sosial bersifat manusiawi, karena hakekatnya adalah untuk dikomunikasikan dalam berbagai media, salah satunya adalah dari konteks kegiatan upacara keagamaan.

Kehadiran fungsi sosial perempuan Bali dalam ritual keagamaan mencakup tiga faktor yang saling berhubungan yakni si penyelenggara upacara, yang menangani upacara, dan penduduk yang berfungsi sebagai pendukung. Ketiga faktor yaitu panitia, pelaksana dan pendukung, merupakan kesatuan yang tidak dapat dipisahkan, atau menjadi sebuah lingkaran setan, yang satu menunjuk yang lain.

Dalam hal ini fungsi sosial dipahami bahwa kehadiran perempuan ditengah-tengah upacara ritual sebagai penguat kesetiakawanan sosial Hindu khususnya. Perempuan mempunyai fungsi ini telah berlangsung cukup lama, contohnya dalam acara memendet yang sangat terkait dengan kesenian tari wali. Kraus, 1969 (dalam Spencer, 1985) mencontohkan dalam penelitian-penelitian seni misalnya, masyarakat primitif melakukan kegiatan-kegiatan ritmis (menari) yang cukup sederhana secara bersama-sama, sebagai ungkapan kesetiaan dan kesatuan suku. Berkaitan dengan hal tersebut, Soedarsono $(1977 ; 1992)$ menuturkan "sampai sekarang beberapa tarian jenis itu sebagai aktivitas yang berhubungan dengan hiburan sosial.

Sehubungan dengan hal itu dalam pemahaman selanjutnya, kedudukan atau peran seni dalam agama sebenarnya merupakan kesatuan dalam fungsi yang sama. Seperti yang di lontarkan Friess, (1954: 15) "Agama juga dipahami sebagai bagian dunia imajinasi yang sangat penting yang berfungsi secara sosial". Sejauh mana agama dilihat dari fungsi ini, bagi pengikut teori fungsional, memandang sebagai hasil dari tiga karakteristik dasar eksistensi manusia hidup bermasyarakat, yaitu manusia hidup dalam kondisi "ketidakpastian", kondisi manusia dalam kaitan konflik antara keinginan dan kenyataan ditandai oleh 
"ketidakberdayaan", dan manusia (masyarakat) berada di tengah-tengah kondisi "kelangkaan". Ketiga karakteristik yang bersifat sosial itu akan membawa manusia, dan hanya bisa dijawab oleh hal-hal yang bersifat transenden. Dan di sinilah fungsi sosial agama akan manjawab masalah-masalah itu.

Seiring dengan pernyataan Cliford Geertz. 1992 (dalam Ruastuti. 2004: 43) menyatakan bahwa pandangan perempuan Bali tentang identitas pribadi terwujud melalui sejauh mana perempuan Bali sebenarnya melukiskan semua orang, seperti: teman-teman, sanak keluarga, para tetangga, dan orang asing, baik secara vertikal maupun horizontal, tanpa membedakan jenis kelamin dan umur. Masing-masing susunan simbolis tentang devinisi pribadi yang disembunyikan sampai gelar-gelar yang idealisasi, dan generalisasi yang tersirat dalam hubungan para individu.

Ritual agama dan pengalaman estetis (seni) sebagai salah satu bentuk perilaku perempuan Bali dengan berdasarkan norma-norma yang dianut secara bersama, telah diciri sebagai fungsi sosial pemersatu aspirasi manusia yang paling luhur dan indah. Sejumlah besar norma, moralitas sebagai sumber tatanan yang telah dipadu dengan nilai-nilai kesakralan dan keindahan (seni) yang mengandung juga unsur-unsur kebaikan, maupun kebenaran, membuat manusia makin beradab. Soetrisno, (1999: 45) mengatakan "manusia yang "buta seni" akan mudah bertindak tanpa pertimbangan kemanusiaan, mengarah kepada budaya kekerasan, dan menjadi manusia biadab". Kehadiran keindahan seni di sini dilihat sebagai lencana bagi kebenaran moral, dan di sini dilihat sebagai lencana bagi kebenaran moral, dan ditangkap dengan maksud-maksud etis. Kedudukan elemen estetis dalam sistem agama seperti itu sungguh nyata dan hakiki, sehingga berada dalam kesadaran pemahaman para pelakunya. Dengan kata lain kedudukan seni dalam agama sebagai bagian dari keseluruhan sistem sosial itu sungguh-sungguh mempunyai fungsi manifest atau diharapkan.

Kedudukan perempuan Bali dalam konteks ritual agama Hindu sebagai sesuatu yang akrab, yakni mendorong rasa kesenangan berkumpul bersama dengan rasa "cinta-kasih" sebagaimana menjadi ajaran utamanya. Dorongan itu imanent, karena sifat-sifat estetis inherent pada setiap manusia dalam segala tindakannya. Terutama dalam seluruh struktur Liturgi Hindu yang intinya adalah rasa syukur (bergembira) atas misteri yang intinya adalah rasa syukur (bergembira) atas misteri karya keselamatan Tuhan dalam Hindu, elemenelemen estetis dalam simbol-simbol seni yang hadir dalam liturgy itu, akan mendorong perasaan syukur-bergembira. Dalam Mazmur disebutkan, dengan "sorak-sorai" atau "dalam keramaian".

Umat Hindu sangat memahami, bahwa pengalaman keimanan tak dapat dipisahkan dengan pengalaman estetis (seni). Karya seni yang serba "indah" mewujudkan pula keluhuran terhadap kepercayaan agama). Pengertian itu dipahami karena unsur keindahan seni tidak ada artinya bila tidak mengandung muatan-muatan yang bersifat kebaikan, kebenaran dan juga keluhuran manusia.

Kehadiran seni dalam upacara keagamaan dapat mewujudkan sifat kebersamaan dan toleransi sesama pengikut kepercayaan lain, baik dari sejak persiapan sampai pelaksanaannya perempuan Bali ikut berpartisipasi dalam kegiatan seni yang ditampilkan dalam upacara atau perayaan itu. Masyarakat setempat yang tidak seiman tertarik membantu pelaksanaan perayaan itu, menganggapnya sebagai kegiatan moral kegotong-royongan sesame warga desa, dan atas dorongan estetis itu sendiri. Melalui ritual agama yang penuh dengan berbagai macam simbol seni tidak hanya merupakan alat efektif untuk menghimpun umat komunitas, tetapi juga memantapkan solidaritas dan koherensi kelompok. Perempuan Bali yang tampil dalam kegiatan itu menyadari ataupun merasakan suatu keikutsertaan, kebersamaan, menyegarkan kontak sosial yang masa-masa seperti sekarang ini jarang terjadi karena disibukkan oleh berbagai macam urusan yang bersifat duniawi. 
Upacara atau perayaan yang penuh dengan pengalaman keimanan dan pengalaman estetis ini, merupakan sesuatu yang sangat berharga, yang telah diperankan oleh agama dalam kehidupan masyarakat pedesaan, dengan sifat-sifat kegotong-royongannya.

\section{Memperkuat Rasa Solidaritas}

Di samping fungsi sosial masyarakat, konteks ritual keagamaan perempuan di Bali merasa menjadi satu komunitas yang satu, utuh. Jalinan persaudaraan menjadi lebih kuat. Semangat kebersamaan dan kuatnya ikatan kolektivitas masyarakat adat terjadi karena kesadaran bahwa manusia tidak mungkin hidup seorang diri dan secara sendiri-sendiri.

Semangat kebersamaan dan rasa persaudaraan yang kental dalam kehidupan masyarakat desa pekraman ini sesuai dengan pandangan E. Durkheim bahwa upacara keagamaan berfungsi sebagai sarana pengembangan rasa paguyuban "sense of community" melalui kegiatan-kegiatan bersama dalam upacara-upacara, seperti kelahiran, perkawinan dan kematian (Koentjaraningrat, 1985: 87). Kegiatan keagamaan, yang membutuhkan pengerahan dana dan tenaga, menyebabkan orang saling membutuhkan serta saling tergantung. Pada gilirannya kesalingtergantungan ini menumbuhkan solidaritas yang kokoh diantara para warganya.

Rasa kebersamaan yang kokoh juga menjadi tulang punggung bagi keselarasan hubungan antar individu, yang sangat penting peranannya di dalam pelaksanaan berbagai aktivitas sosial. Oleh karena itu Gorda (1997: 38) menegaskan dalam sistem kehidupan masyarakat Hindu di Bali, kebersamaan dan keselarasan merupakan ciri khas yang dominan.

Sesuai dengan teori B. Malinowski bahwa sagala aktivitas kebudayaan itu sebenarnya bermaksud memuaskan suatu rangkaian dari sejumlah kebutuhan naluri makhluk manusia yang berhubuingan dengan seluruh kehidupannya. Kegiatan keagamaan sebagai salah satu contoh dari salah satu unsur kebudayaan misalnya terjadi karena mula-mula manusia ingin memuaskan kebutuhan nalurinya akan keindahan.

Kebersamaan perempuan dalam satu komunitas keagamaan merupakan wahana untuk mengekspresikan pengabdian, bakat astetis sekaligus berfungsi sebagai ajang diskusi non formal. Perempuan dalam konteks ritual keagamaan dikatakan mampu meningkatkan rasa solidaritas karena eksistensi ini berkaitan dengan kehidupan masyarakat dan segala aktivitas keagamaannya yang tak dapat dilepaskan dari eksistensi serta aktivitas masyarakat pendukungnya. Kehadirannya di tengah-tengah masyarakat pendukung mencakup dua hal yaitu si pelaku dan si pendukung. Seperti yang diungkap Smith dalam Koentjaraningrat (1987: 67) menyatakan upacara religi atau agama yang dilaksanakan oleh banyak warga masyarakat pemeluk religi atau agama bersangkutan secara bersama-sama mempunyai fungsi sosial untuk mengintensifkan solidaritas masyarakat, karena perempuan Bali menganggap melakukan upacara adalah kewajiban sosial. Maka dengan demikian dapat ditarik benang merah bahwa suguhan kesenian yang relevansinya dengan upacara keagamaan selain memiliki fungsi ritual juga memiliki fungsi sosial untuk meningkatkan rasa solidaritas masyarakat.

Segala kegiatan yang bernuansa sakral dalam konteks ritual mempunyai hubungan yang sangat erat dengan kehidupan masyarakat pengempon atau pemaksan dan masyarakat pendukungnya. Hal ini merupakan fungsi yang penting dalam kehidupan baik sosial maupun spiritual. Seperti yang diungkap oleh pakar kebudayaan Indonesia soedarsono (1999, dalam Kusumari, 2004 : 117) menyatakan agama dan budaya dalam kehidupan manusia memiliki bermacam-macam fungsi, salah satu diantaranya adalah berfungsi sebagai pengikat solidaritas nasional. Senada dengan Wibowo (2000 : 58) mengungkapkan bahwa bentuk kegiatan ritual yang dilakoni perempuan Bali umumnya dilakukan untuk kepentingan upacara adat mempunyai fungsi sosial yang sangat penting. Ia dapat memberikan dorongan 
solidaritas kepada masyarakat dalam rangka mempersatukan, kemauan, niat, dan perasaan perempuan Bali dalam menjalankan upacara tersebut.

Kemauan dan kekompakan dalam melaksanakan upacara dalam kaitannya dengan konteks ritual yang ada pada masyarakat tercermin dari bukti-bukti banten atau alat upakara yang digarap secara apik oleh tangan-tangan perempuan Bali.

\section{PENUTUP SIMPULAN}

Berdasarkan keseluruhan proses penelitian, maka diperoleh beberapa hal penting berkaitan dengan fungsi dan peranan wanita yakni fungsi wanita yakni fungsi sosia masyarakat dan yang kedua fungsi memperkuat rasa solidaritas sedangkan peranan wanita dalam upaya transformasi nilai-nilai keagamaan dan pembagian tanggungjawab pelaksanaan dan pembangunan keagamaan adalah bersifat berkesinambungan.

\section{SARAN}

Dari sudut pandang agama Hindu, perempuan memiliki kedudukan yang mulia. Sebuah keluarga akan terlihat bahagia apabila mampu memberikan penghargaan dan penghormatan kepada perempuan di rumah itu baik itu Ibu, ataupun Istri. Begitu pula seorang perempuan juga hendaknya mampu menjaga diri didalam suatu pergaulan. Perempuan yang mampu menjalankan semua tugas dan kewajibannya serta perempuan yang berpendidikan, akan dapat menghasilkan generasi - generasi yang berpendidikan karena orang tua adalah seorang guru didalam keluarga. Dengan demikian, perempuan dan laki-laki memiliki peran yang sejajar karena dalam agama Hindu keduanya diciptakan oleh Ida Sang Hyang Widhi Wasa.

\section{DAFTAR PUSTAKA}

Acee Suryadi. Aceep Idris. 2004. Kesetaraan Gender dalam Bidang Pendidikan. Jakarta: PT Genesindo.

Achmad. Muthia'in. 2001. Bias Gender dalam Pendidikan. Surakarta: UMS.

Elfi Muawanah. 2009. Pendidikan Gender dan Hak Asasi Manusia. Yogyakarta: TERAS.

Fakih Mansour. 1996. Analisis Gender dan Transformasi Sosial. Yogyakarta:Pustaka Pelajar.

Maswinara, I Wayan. 1999. Rgveda Samhita. Surabaya: Paramita Pudja, Gede. 1977. Manawa Dharma Sastra. Jakarta: Dep.Agama R.I.

Pandit., I Nyoman. 1993. Saracamuscaya. Jakarta ; Hanuman Sakti. Pudja. SH MA. I Gede. 1988. Bhagawadgita. Jakarta: Hanuman Sakti.

Sri Awati. Ni Made. 1993. Swadharma Ibu Dalam Keluarga Hundu. Denpasar: Upada Sastra 